\title{
Mindfulness: a path towards psychological well-being.
}

\author{
Prasanna Jayatilake* \\ Global Minds (Private) Limited, Sri Lanka
}

Accepted on September 25, 2017

Mindfulness is an increasing trend in modern psychology and it has gained much attention in the scientific arena as well [1]. Mindfulness has considered as the third wave of cognitive behavior therapies [2] and it is a widely researched area in contemporary practice of psychology and medicine [3].

The concept of mindfulness has its roots in the Buddhist philosophy $[4,5]$ and it is a central phenomenon in Buddhist teachings [6]. There are various definitions for mindfulness in contemporary practice; however, the most accredited definition developed thus far is by Prof. Kabat-Zinn [4], in which mindfulness is defined as "paying attention in a particular way; on purpose, in the present moment and non-judgmentally".

In the fields of Psychology and Psychiatry, mindfulness has used the concept of mindfulness, and it has emerged as "MindfulnessBased Interventions (MBIs), where the clients have received effective therapeutic outcomes, enhanced general wellbeing and quality of life $[7,8]$. In this circumstance, it is important to investigate how mindfulness makes the path towards enhancing wellbeing.

Psychological wellbeing refers to the "combination of positive affective states such as happiness and functioning with optimal effectiveness in individual and social life" [9]. In the model of psychological wellbeing developed by [10] it discusses six aspects; functioning autonomy, environmental mastery, personal growth, positive relations with others, purpose of life and self-acceptance. The aforesaid parameters of psychological wellbeing have direct links with mindfulness, where its influence of cognitive neuro-biological changes are concerned [11-13].

The components of psychological wellbeing are derived through the enhanced function of brain and limbic system [14,15] which includes hippocampus, thalamus, hypothalamus, basal ganglia, cingulate gyrus and amygdala $[16,17]$. They are responsible for higher mental functioning. Amygdala is the emotional regulation part of the brain and hippocampus is responsible for memory $[17,18]$. The limbic system is also known as the "emotional nervous system" since it is responsible for emotional regulation. There many empirical research in contemporary practice to study the contribution in mindfulness to achieve such higher levels of cognitive functions. These changes within the brain happen in the level of neuro-biological aspects $[3,19]$.

Holzel and Carmody [9] have found by examining the participants who have exposed to consecutive 8 weeks MBSR program and with the usage of Anatomical Magnetic Resonance Imaging, it resulted increased gray matter concentration in the left hippocampus. Therefore, it is evident that the practice of mindfulness helps to fulfill the parameters of psychological well-being.
The concept of mindfulness is derived from the Buddhist philosophy $[3,7]$ which is originated with the main focus to cessation from all sufferings and attains the ultimate blissful state, nibbāna [20]. It is attained through following a sequential process; Noble Eight Fold Path [21], which begins with the understanding of the true nature of existence, as explained in trilaksana (anicca: things do not happen according to one's desire; dukkha: suffering created through the nature of being anicca and anatta: worthlessness), and being mindful about the aforesaid true nature of the world [22].

However, the term "mindfulness" used in contemporary practice does not aim at achieving such level of wisdom, but to enhance worldly wellbeing, which would enable an individual to gain quality of life $[6,23,24]$. In order to achieve this state, some general mindfulness techniques; such as simple relaxation, observation of breath, mindful walking, mindful eating can be utilized [6,25]. With regular practice, an individual would gain better mental stability, as a result of the changes happening within the cognitive neuro-biological level [1,26].

It is important to note that a little change in your schedule to have some time to practice these techniques would bring about psychological well-being, which would be directed to have abundant of success and happiness that you wish to accomplish in life.

\section{Reference}

1. Malinowski P. Neural mechanisms of attentional control in mindfulness meditation. Focused Review. 2013;8(7).

2. Kahl KG, Winter L, Schweiger U. The third wave of cognitive behavioral therapies: What is new and what is effective? Curr Opin Psychiatry. 2012;25(6):522-8.

3. Brown KW, Ryan RM. Mindfulness: Theoretical foundations and evidence for its salutary effects. Psychol Inq. 2003;4(18):211-37.

4. Kabat-Zinn J. Where you go, there you are: Mindfulness meditation in everyday life. New York: Hyperion. 1994.

5. Grepmair L, Mitterlehner F, Loew T, et al. Promoting mindfulness in psychotherapists in training influences the treatment results of their patients: A randomized, double-blind, controlled study. Psychother Psychosom. 2007;76(6):332-8.

6. Kabat-Zinn J. Mindfulness-based interventions in context: past present \& future. Mindfulness. 2013;2(10):144-56

7. Keng SL, Smoski MJ, Robins CJ. Effects of mindfulness on psychological health: A review of empirical studies. Clin Psychol Rev. 2011;31(6):1041-56. 
8. Shonin E, Gordon WV, Griffiths MD. Mindfulness-based interventions: towards mindful clinical integration. Front Neurosci. 2013;4.

9. Holzel BK, Carmody J, Vangel M, et al. Mindfulness practice leads to increases in regional brain gray matter density. Psychiatry Res.2011;191(1):36-43.

10. Ryan RM, Deci EL. Self-determination theory and the facilitation of intrinsic motivation, social development and well-being. Am Psychol. 2000;55:68-78.

11. Ryff CD, Singer B. The contours of positive human health. Psychol Inq.1998;9:1-28.

12. Tang Y, Ponser M. Theory and method in mindfulness neuroscience. Soc Cogn Affect Neurosci. 2013;8:118-20.

13. Bressler S, Menon V. Large scale brain networks in cognition: Emerging methods and principles. Trends Cogn Sci. 2010;14:277-90.

14. Frodl T, Jager M, Smajstrlova I, et al. Effect of hippocampal and amygdala volumes on clinical outcomes in major depression: A 3 year prospective magnetic resonance imagining study. J Psychiatry Neurosci. 2008;33:423-30.

15. Grawe K. Neuropsychotherapy: How the neurosciences inform effective psychotherapy. New York, NY: Psychology Press.

16. Rolls ET. Limbic Structures, emotion, and memory. In: Stein, John (ed.) Reference Module in Neurosci Biobehav Psychol. Elsevier 2017.

17. Siegel DJ, Guilford. The developing mind: Toward a neurobiology of interpersonal experience. New York, NY.1999.
18. Rolls ET. Limbic systems for emotion and memory, but no single limbic system. Cortex. 2015;62:119-57.

19. Marciniak R, Sheardova K, Hudecek D, et al. Effect of meditation on cognitive functions in context of aging and neurodegenerative diseases. Front Behav Neurosci. 2014;8:17.

20. The Tripitaka Editorial Board. Buddha Jayanti Tripitaka Series; Vol 12 (iii); Majjhimanikāya: III(6). Venerable Pandita Sumanasāra, K. (Ed.) Sri Lanka: Buddhist Cultural Center. Accessed on 2016.

21. The Tripitaka Editorial Board. Buddha Jayanti Tripitaka Series; Vol 17 (ii); Samyuttanikāya: V-2 (11). Samyuttanikāya Editorial Board (Ed.) Sri Lanka: Buddhist Cultural Center. Accessed on 2016.

22. The Tripitaka Editorial Board. Buddha Jayanti Tripitaka Series; Vol 16; Samyuttanikāya: IV (10). Samyuttanikāya Editorial Board (Ed.) Sri Lanka: Buddhist Cultural Center. Accessed on 2016.

23. Nelson DL. Implementing mindfulness: Practice as the home of understanding. Paideusis. 2012;20(2):4-14.

24. Jayatilake, P. Integration of the Buddhist concept of mindfulness (BCM) into counselling: Experiences of counsellors. J Psychol. 2016;7:2.

25. Hoyt W. Teaching with mindfulness: The pedagogy of being-with/for and without being-with/for. Journal of Curriculum Theorizing. 2016;31(1):126-42.

26. Phang C, Oei TPO. From mindfulness to meta-mindfulness: Further integration of meta-mindfulness concept and strategies into cognitive behavioral therapy. Mindfulness. 2012;2(3):104-16.

\section{*Correspondence to:}

Prasanna Jayatilake

CEO/Director

Counselling and Training - Global Minds (Private)

Limited

Sri Lanka

Tel: +94 (0) 773277558

E-mail: prasannajayatilake@yahoo.com 